\title{
Practical aspects of bacterial culture for the diagnosis of bacterial kidney disease (BKD)
}

\author{
Anne Berit Olsen ${ }^{1}$, Petter Hopp ${ }^{1}$, Martin Binde ${ }^{1}$, Hallstein Grønstøl ${ }^{2}$ \\ 'State Veterinary Laboratory in Bergen, PO Box 40, N-5032 Minde, Norway \\ ${ }^{2}$ Norwegian College of Veterinary Medicine, PO Box 8146 Dep., N-0033 Oslo 1, Norway
}

\begin{abstract}
A study was made of practical aspects of culture of Renibacterium salmoninarum (R.s.) from the kidney of Atlantic salmon Salmo salar. Samples were taken from fish in sea farms affected by outbreaks of bacterial kidney disease (BKD). Only $67 \%$ of the samples positive for growth of R.s. on kidney disease medium (KDM2) were positive on selective kidney disease medium (SKDM). Of the samples positive on KDM2, $98 \%$ were identified as positive after 8 wk of incubation at $15^{\circ} \mathrm{C}$, whereas only $82 \%$ of the samples positive on SKDM were positive at this time. Growth of R.s. on KDM2 produced more colonies than growth on SKDM. No significant differences in isolation frequency were seen between culture from anterior and posterior kidney. If 3 or 4 inoculations were made from each fish, the number of R.s.-positive fish increased by $44 \%$ in the lightly infected population of this study. Both storage of the sample material on swabs in 2 different modifications of Stuart's transport medium for $24 \mathrm{~h}$, and freezing at $-20^{\circ} \mathrm{C}$ for 3 to 4 mo, reduced the sensitivity of culture from lightly infected samples.
\end{abstract}

\section{INTRODUCTION}

Bacterial kidney disease (BKD) has been recognized in salmonids in a number of countries and causes serious losses in cultured salmonids. BKD may occur as an acute necrotizing infection or as a chronic granulomatous inflammatory condition (Bruno 1986). The disease is caused by Renibacterium salmoninarum (R.s.), a small Gram-positive diplobacillus (Sanders \& Fryer 1980) that occurs primarily intracellularly in macrophages where it appears to survive and multiply (Young \& Chapman 1978, Bruno 1986, Bandín et al. 1991).

BKD was diagnosed for the first time in Norway in 1980 (Håstein \& Dale 1987). In Norway, the disease is notifiable and fish must be certified free of BKD if they are to be moved.

As culture is a highly specific method for the demonstration of R.s. in fish (Austin \& Austin 1987) and has also repeatedly proved to be a very sensitive method (Evelyn et al. 1981, Austin \& Austin 1987, Paclibare et al. 1988, Shortt et al. 1988), bacterial isolation is used routinely in the confirmatory diagnoses of $\mathrm{BKD}$ in Norway. The purpose of the present investigation was to test practical aspects of culture for Renibacterium salmoninarum that might affect the usefulness of the method.

We studied the relationships between culture results, clinical observations, and post-mortem findings, and we examined whether or not the part of the kidney sampled affected the results. We also compared the sensitivity of the 2 culture media KDM2 and SKDM. and determined optimal incubation periods. Finally, we tested the suitability of using swabs for the submission of samples for laboratory investigation, the effect of freezing on the culture results, and the effect of homogenising the kidney material before inoculation onto the culture medium.

\section{MATERIALS AND METHODS}

Fish. A total of 870 Atlantic salmon Salmo salar from 7 fish farms affected by outbreaks of BKD were sampled (see Table 1). The fish had been in sea water for 8 to 12 mo. Based on clinical observations (external examination) the fish were divided into the following 3 groups: healthy looking, moribund, and dead. Healthy looking fish were collected by catching fish 
that came for feed. Dead fish were collected twice a week. For practical reasons, 455 of the moribund and dead fish were kept frozen at $-20^{\circ} \mathrm{C}$ for 2 to $30 \mathrm{~d}$ before post mortem examination. Fresh fish were examined the same day or the day after they were sampled.

Before post mortem examination, the body surface of the tish was disinfected with $70 \%$ ethanol. Sterile equipment was used for necropsy.

On the basis of internal examination, fish were divided into 2 subgroups: those with visible signs of BKD (white nodules in internal viscera or swollen kidney without white nodules) and those with no visible signs of BKD.

Bacteriological examination. Cultures for R.s. were obtained from the kidney with a wire loop. Inocula from fish with internal BKD-like findings were obtained from the areas with lesions, primarily the posterior kidney. For fish with no internal signs of BKD, the inocula were obtained from the posterior kidney. In 266 cases, regardless of post mortem findings, an inoculum was taken from the anterior and posterior kidney for comparative purposes.

The 2 special media employed were the kidney disease medium (KDM2; Evelyn 1977), and the selective kidney disease medium (SKDM; Austin et al. 1983). The media were supplemented with $10 \%$ horse serum. The amount of polymyxin B sulphate in the selective medium was reduced to $0.0015 \% \mathrm{w} / \mathrm{v}(1 \mathrm{mg}=7900 \mathrm{IU})$ to avoid the possibility that polymyxin $B$ sulphate might inhibit growth of Renibacterium salmoninarum (Banner et al. 1986).

The media were used within a month of preparation. Each plate was inoculated with a single loopful of sample from each of 3 or 4 fish. The plates were incubated in polyethylene bags at $15^{\circ} \mathrm{C}$ for 12 to $13 \mathrm{wk}$. If mould growth was seen, the plates were sealed and sometimes also placed in separate bags.

The plates were examined for up to 7 times during the incubation period and the number of R.s. colonies was recorded as ' $1-100$ ' and ' $>100$ ' Cultures that were overgrown with mould and/or other bacteria were discarded.

Milky white colonies were confirmed as Renibacterium salmoninarum if they were catalase-positive and cytochrome oxidase-negative, and if they were comprised of small Gram-positive diplobacilli. When BKD was initially diagnosed on a fish farm, and in doubtful cases, the bacterium was also identified using the API-ZYM test (Goodfellow et al. 1985), testing its inability to grow on blood agar incubated at $22^{\circ} \mathrm{C}$ for $5 \mathrm{~d}$, or examing fluorescence in the indirect fluorescent antibody technique (IFAT) with monoclonal antibodies (Wiens \& Kaattari 1989).

Culture on KDM2 from the kidney with a wire loop was compared with culture on KDM2 from the kidney material after storage for 20 to 24 h on 2 different swab systems. Swab system A (Marion Scientific's Mini-Tip Culturette) utilised rayon-tipped swabs in modified Stuart's transport medium (sodium glycerophosphate $1.0 \%$, sodium thioglycolate $0.1 \%$, calcium chloride dihydrate $0.01 \%$, and water); the swabs were stored at 4,15 , and $22^{\circ} \mathrm{C}$. Swab system B consisted of cottontipped wooden sticks in SIFF transport medium, another modification of Stuart's transport medium [Sandven et al. 1982; agar (Difco) $8 \mathrm{~g}$, sodium glycerophosphate $1 \mathrm{~g}$, starch (soluble; Difco) $10 \mathrm{~g}, \mathrm{NaCl} 3.5 \mathrm{~g}$, $\mathrm{KCl} 3 \mathrm{~g}, \mathrm{Na}_{2} \mathrm{HPO}_{4} \cdot 12 \mathrm{H}_{2} \mathrm{O} 3 \mathrm{~g}, \mathrm{KH}_{2} \mathrm{PO}_{4} 0.4 \mathrm{~g}$, distilled water $1000 \mathrm{ml}, 0.1 \mathrm{M} \mathrm{MgCl}_{2} 1 \mathrm{ml}, 0.1 \mathrm{M} \mathrm{CaCl}_{2} 1 \mathrm{ml}$, L-cysteinehydrochloride $0.025 \mathrm{~g}$, thioglycolate $0.5 \mathrm{ml}$, methylene blue $(0.1 \%$ in water) $2 \mathrm{ml}$; final $\mathrm{pH} 7.1]$. These swabs were stored at $15^{\circ} \mathrm{C}$.

Samples of kidney tissue from 334 of the fresh fish (282 healthy looking and 52 moribund and dead) were cultured on $\mathrm{KDM} 2$ before and after storage at $-20^{\circ} \mathrm{C}$ for 3 to 4 mo.

Fresh kidney material from 40 fish (11 healthy looking and 29 moribund) was also homogenised, undiluted, in a Stomacher Lab-Blender 80 for $10 \mathrm{~min}$ before inoculation with a wire loop onto KDM2. Our purpose was to determine whether homogenisation increased the sensitivity of the culture results over that obtained with non-homogenised samples.

Statistical calculations. Estimations of statistical significance were determined using the chi-square test and McNemar's chi-square test (Martin et al. 1988). $p$ values less than 0.05 were considered to be statistically significant. In making comparisons, estimations were only made on the basis of paired samples from the same individuals

\section{RESULTS}

Culture results seen in relation to clinical observations and post mortem findings. Compared with fish in the healthy looking group, fish in the fresh and frozen dead and moribund groups consistently showed higher frequencies of internal lesions (64 to $87 \%$ vs $26 \%$ ), R.s.-positive samples (66 to $88 \%$ vs $14 \%$ ), and high colony counts (79 to $100 \%$ vs $55 \%$ ) (Tables $1 \& 2$ ). Because of this, and to simplify analysis of the data, all comparisons of data in this paper are made between pooled data for the fresh and frozen dead and moribund groups (designated the 'dead and moribund' group) and the healthy looking group.

For the group of healthy looking fish only $38 \%$ of the individuals with internal lesions indicative of BKD and only $6 \%$ of the individuals without internal BKD-like lesions were positive for R.s. on KDM2 (Table 1). 
Table 1 Salmo salar kidney sampled for Renibacterium salmoninarum. Number of Atlantic salmon examined, number and frequency of specimens with internal BKD-like lesions, number and frequency of specimens showing growth of R.s. on KDM2 from posterior kidney or lesions, number and frequency of specimens with internal BKD-like lesions that also were positive for R.s. on KDM2, and number and frequency of specimens that were positive for R.s. on KDM2 but did not have internal BKD-like lesions

\begin{tabular}{|c|c|c|c|c|c|c|c|c|c|}
\hline \multirow[t]{2}{*}{$\begin{array}{l}\text { Category of } \\
\text { fish }\end{array}$} & \multirow{2}{*}{$\begin{array}{l}\text { (A) Fish } \\
\text { examined } \\
n\end{array}$} & \multicolumn{2}{|c|}{$\begin{array}{c}\text { (B) With } \\
\text { internal } \\
\text { BKD lesions }\end{array}$} & \multicolumn{2}{|c|}{$\begin{array}{l}\text { Positive } \\
\text { on culture }\end{array}$} & \multicolumn{2}{|c|}{$\begin{array}{l}\text { With internal BKD } \\
\text { lesions and posi- } \\
\text { tive on culture }\end{array}$} & \multicolumn{2}{|c|}{$\begin{array}{l}\text { No internal BKD } \\
\text { lesions but posi- } \\
\text { tive on culture }\end{array}$} \\
\hline & & $\mathrm{n}$ & $(1 \%)$ & $\mathrm{n}$ & {$[\%]$} & $\mathrm{n}$ & $(\%$ of $B)$ & $\mathrm{n}$ & $(\%$ of $A-B)$ \\
\hline Moribund, fresh & 77 & 49 & (64) & 51 & $(66)$ & 44 & $(90)$ & 7 & (25) \\
\hline Moribund, frozen & 112 & 89 & (79) & 98 & (88) & 82 & (92) & 16 & $(70)$ \\
\hline Dead, fresh & 38 & 33 & (87) & 32 & $(84)$ & 32 & (97) & 0 & $(0)$ \\
\hline Dead, frozen & 343 & 277 & (81) & 293 & $(85)$ & 255 & $(92)$ & 37 & (56) \\
\hline Total moribund/dead & 570 & 448 & (79) & 474 & $(83)$ & 413 & (92) & 60 & (49) \\
\hline Healthy looking & 300 & 79 & $(26)$ & 43 & $(14)$ & 30 & $(38)$ & 13 & $(6)$ \\
\hline Total & 870 & 527 & (61) & 517 & (59) & 443 & (84) & 73 & (21) \\
\hline
\end{tabular}

Table 2. Salmo salar kidney sampled for Renibacterium salmoninarum. Distribution and frequency of colony counts on KDM2 from posterior kidney or kidney lesions, for the different categories of Atlantic salmon tested

\begin{tabular}{|c|c|c|c|c|c|}
\hline \multirow{3}{*}{$\begin{array}{l}\text { Category of } \\
\text { fish }\end{array}$} & \multirow{3}{*}{$\begin{array}{l}\text { Total no. } \\
\text { samples }\end{array}$} & \multicolumn{4}{|c|}{ Colony count } \\
\hline & & \multicolumn{2}{|c|}{$1-100$} & \multicolumn{2}{|c|}{$>100$} \\
\hline & & $\mathrm{n}$ & $(\%)$ & $\mathrm{n}$ & $(\%)$ \\
\hline Moribund, fresh & 44 & 5 & (11) & 39 & (89) \\
\hline Moribund, frozen & 98 & 6 & (6) & 92 & (94) \\
\hline Dead, fresh & 32 & 0 & (0) & 32 & $(100)$ \\
\hline Dead, frozen & 293 & 61 & $(21)$ & 232 & (79) \\
\hline Total moribund/dead & 467 & 72 & (15) & 395 & (85) \\
\hline Healthy looking & 42 & 19 & $(45)$ & 23 & (55) \\
\hline Total & 509 & 91 & $(18)$ & 418 & $(82)$ \\
\hline
\end{tabular}

Samples from healthy looking fish were also to a large extent $(45 \%)$ lightly infected, producing growth of less than 100 R.s. colonies (Table 2).

For moribund and dead fish $92 \%$ of the fish with internal BKD-like lesions and $49 \%$ of the fish without internal BKD-like lesions were positive on culture on KDM2 (Table 1). The majority of the samples from these fish $(85 \%)$ were heavily infected, producing more than 100 R.s. colonies on KDM2 (Table 2).

Number of samples per fish. The number of healthy looking fish that were positive on culture increased from 36 to $52(44 \%)$ when the number of samples tested per fish was increased from 1 to 3 or 4 . Increasing the number of samples tested per fish only slightly enhanced recovery of R.s. from moribund and dead fish (data not shown).

Culture from the posterior kidney compared to the anterior kidney. Most of the fish (92\%) that were positive for growth of R.s. on KDM2 from the posterior kidney were also positive on KDM2 from the anterior kidney $(n=135)$. The difference in frequency of positive results was not statistically significant.

Culture on KDM2 compared with SKDM. Only $67 \%$ of the samples positive for R.s. on KDM2 were also positive on SKDM ( $n=389)$ (Table 3). The difference in culture results between KDM2 and SKDM was statistically significant $(p<0.001)$. There were also signifi-

Table 3. Relative efficacy of KDM2 and SKDM at detecting Renibacterium salmoninarum in Salmo salar kidney lesions or posterior kidney samples (number of samples positive $(+)$ or negative (-) for R.s.]

\begin{tabular}{|lrrrr|}
\hline & & \multicolumn{2}{c}{ SKDM } & Total \\
& & + & - & \\
\hline KDM2 & + & 262 & 127 & 389 \\
& - & 10 & 297 & 307 \\
Total & & 272 & 424 & 696 \\
\hline
\end{tabular}


Table 4. Salmo salar kidney sampled for Renibacterium salmoninarum. Number and frequency of samples positive for R.s. after storage for 20 to $24 \mathrm{~h}$ at 4,15 and $22^{\circ} \mathrm{C}$ of the kidney material on System-A swabs in modified Stuart's transport medium compared to culture on KDM2 before storage using a wire loop directly from the kidney

\begin{tabular}{|c|c|c|c|c|c|c|}
\hline \multirow[t]{2}{*}{$\begin{array}{l}\text { Category of } \\
\text { fish }\end{array}$} & \multicolumn{2}{|c|}{$\begin{array}{l}4^{\circ} \mathrm{C} \\
\text { Positive after/ } \\
\text { positive before }\end{array}$} & \multicolumn{2}{|c|}{$\begin{array}{l}15^{\circ} \mathrm{C} \\
\text { Positive after/ } \\
\text { positive before }\end{array}$} & \multicolumn{2}{|c|}{$\begin{array}{c}22^{\circ} \mathrm{C} \\
\text { Positive after/ } \\
\text { positive before }\end{array}$} \\
\hline & $\mathrm{n}$ & $\%$ & $\mathrm{n}$ & $\%$ & $\mathrm{n}$ & $\%$ \\
\hline Healthy looking & $24 / 37$ & 65 & $8 / 17$ & 47 & $9 / 36$ & 25 \\
\hline Moribund and dead & $56 / 65$ & 86 & $107 / 140$ & 76 & $47 / 124$ & 38 \\
\hline Total & $80 / 102$ & 78 & $115 / 157$ & 73 & $56 / 160$ & 35 \\
\hline
\end{tabular}

cantly more samples that produced less than 100 R.s. colonies on SKDM $(13 \%)$ than on KDM2 (3\%) $(\mathrm{n}=$ $262, \mathrm{p}<0.001)$.

By the end of Week $8,98 \%$ of all positive cultures on KDM2 showed visible growth $(n=500)$, whereas only $82 \%$ of the SKDM positive cultures had become visible at this stage ( $\mathrm{n}=271$ ) (Fig. 1 ).

Due to contamination and overgrowth, $2 \%$ of the samples cultured on KDM2 and $8 \%$ of the samples cultured on SKDM were discarded $(n=754)$. Most (92\%) of the discarded cultures were from dead fish.

Culture from swabs after storage. The number of positive samples from System-A swabs stored for 20 to 24 h at 4,15 and $22^{\circ} \mathrm{C}$ was significantly reduced in each group $\left(\mathrm{p}<0.05\right.$ for $4{ }^{\circ} \mathrm{C}$ and $\mathrm{p}<0.001$ for $15^{\circ} \mathrm{C}$ and $22^{\circ} \mathrm{C}$ ) relative to that for unstored samples (Table 4). The reduction was most marked for samples from healthy looking (lightly infected) fish and for samples stored at $22^{\circ} \mathrm{C}$. There was no significant reduction in sensitivity when culturing from samples stored at $4{ }^{\circ} \mathrm{C}$ from moribund and dead fish.

Only 9 of the 17 samples that were positive before storage on System-B swabs at $15^{\circ} \mathrm{C}$ were positive after

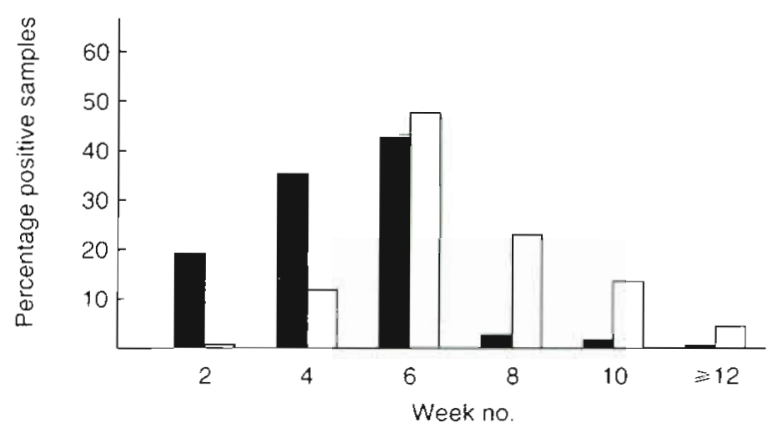

Fig. 1 Salmo salar kidney sampled for Renibacterium salmoninarum. ( Distribution of R.s.-positive cultures on KDM2 over time expressed as a percentage of the total number of R.s.-positıve cultures on $\operatorname{KDM}_{2}(\mathrm{n}=500)$. $(\square)$ Distribution of R.s.-positive cultures on SKDM over time expressed as a percentage of the total number of R.s.-positive cultures on SKDM $(\mathrm{n}=271$ )
Table 5. Effect of freezing $\left(-20^{\circ} \mathrm{C}, 3\right.$ to $\left.4 \mathrm{mo}\right)$ on the ability to recover viable Renibacterium salmoninarum on KDM2 from kidney samples of Atlantic salmon Salmo salar

\begin{tabular}{|lrccc|}
\hline $\begin{array}{l}\text { Category } \\
\text { of fish }\end{array}$ & $\begin{array}{c}\text { No. } \\
\text { tested }\end{array}$ & $\begin{array}{c}\text { No. posi- } \\
\text { tive before } \\
\text { freezing }\end{array}$ & \multicolumn{2}{c|}{$\begin{array}{c}\text { Positive after } \\
\text { freezing }\end{array}$} \\
\hline $\begin{array}{l}\text { Healthy looking } \\
\text { Moribund/dead }\end{array}$ & 282 & 41 & 11 & 27 \\
Total & 52 & 44 & 43 & 98 \\
\hline
\end{tabular}

storage. The samples tested were from moribund and dead fish.

Effect of freezing on culture results. Freezing samples for 3 to 4 mo before culture reduced the sensitivity by $73 \%$ for samples from healthy looking fish (Table 5). There was no reduction in sensitivity for the group of moribund and dead fish.

Effect of homogenisation of samples before culture. Of the 40 samples tested all the 27 that were positive for R.s. on KDM2 before homogenisation were also positive after homogenisation.

\section{DISCUSSION}

Culture of Renibacterium salmoninarum is a highly specific method for the diagnosis of BKD provided the bacterium is adequately identified following its isolation. Several studies have also shown culture to be a very sensitive method for detecting R.s. but other investigations have shown certain serological methods to be superior to culture with regard to sensitivity (Cipriano et al. 1985, Pascho et al. 1987. Sakai et al. 1987, Gudmundsdóttir et al. 1990). Our results showed that culture can fail to confirm a suspicion of BKD based on internal findings, especially in fish that are externally 'healthy looking'. In such cases, one would have to re-examine the samples using the other more sensitive methods. Alternatively, one might resort to 
examining more fish from the suspect population using the culture technique. It has also been shown that the sensitivity of culture can be increased by the nurse culture technique (Evelyn et al, 1989) or by supplementing KDM2 with a small amount of KDM2 broth that has previously been used to grow R.s. (Evelyn et al. 1990). These approaches might also be used for examining suspect samples.

In agreement with Evelyn et al. (1981), Cipriano et al. (1985), Benediktsdóttir et al. (1991) and Gudmundsdóttir et al. (1991), our findings showed that culture can be used to demonstrate bacteria in fish with no external or internal signs of disease, i.e. the so-called latent carriers. As has been well-documented by others, the likelihood of demonstrating R.s. by culture increased significantly when the samples were derived from moribund or dead fish, or from fish with gross signs suggestive of BKD (white nodules in the viscera or swollen kidneys but no visible white nodules).

In agreement with Pascho et al. (1987) there was in our study no significant difference in the frequency of positive samples between culture from anterior and posterior kidney. Closer scrutiny of our results, however, revealed that most $(81 \%)$ of the samples positive on culture were from moribund or dead fish. It is therefore possible that our results will only be valid for fish with relatively heavy bacterial loads. Our findings, therefore, need not necessarily be in conflict with those of Austin \& Rayment (1985), who found that the anterior kidney gave the highest frequency of positives in fish with no external or internal signs of disease.

That culture of several samples from the same fish detected more R.s.-positive fish overall is in good agreement with the results of Pascho et al. (1987) who nearly doubled the prevalence of positive kidneys by combining the results of culture from 3 sections of the kidney. When examining fish with a presumed low bacterial load, several samples should be examined per fish in order to increase the sensitivity of the culture method.

In the present study, KDM2 proved to be a more sensitive medium than SKDM. More samples were positive on KDM2 compared to SKDM, R.s. grew more quickly on KDM2, and growth on KDM2 also produced more colonies. This is in contrast to the findings of Austin et al. (1983), Sakai et al. (1987), and Gudmundsdóttir et al. (1991), who found more positive fish on SKDM than on KDM2. Gudmundsdóttir et al. (1991) did not find any significant difference in growth rate and colony counts for the 2 media. A problem connected with the foregoing investigations was that other bacteria and/or moulds grew on the KDM2 plates. This may have camouflaged or prevented growth of R.s. The growth of other bacteria and moulds was not a great problem in our study, not even when culturing from dead fish. Thus, contamination problems did not significantly influence the results in our study

Our results suggest, however, that the addition of selective components to the medium may suppress the growth of Renibacterium salmoninarum.

In conclusion, we consider that for the routine bacteriological culture of samples from fish, KDM2 medium should be used instead of SKDM if the material is not likely to be contaminated. When culturing material that is presumed to contain other, more rapidly growing, agents, a selective medium in addition to KDM2 has to be employed. According to our results, however the sensitivity and selectivity of the selective medium SKDM need to be improved: not only did we detect fewer R.s.-positive samples with SKDM, but we also had to discard more samples due to contamination on $\operatorname{SKDM}(8 \%)$ than on KDM2 (2\%)

Our findings and those of Benediktsdóttir et al. (1991) suggest that the incubation period for SKDM should be about $12 \mathrm{wk}$. An increase in the incubation period for KDM2 from 8 wk to 12 wk only gave a few more positive samples in our study.

The swab types and transport media, as tested in the present study, did not prove suitable for the dispatch of samples. Results showed that the System-A swab method can only be used when sampling heavily infected material and that the swab must be kept chilled at about $4{ }^{\circ} \mathrm{C}$. As it will probably be difficult under field conditions to keep the swabs sufficiently chilled during the transport period, we find ourselves unable to recommend the tested swabs and transport media tested for submitting samples to the laboratory for BKD culture.

R.s., like other Gram-positive bacteria, should tolerate prolonged freezing. The greatest stress for microorganisms upon freezing is, however, generally not the low temperature itself, but rather the freezing and thawing process(Cottral 1978). It would therefore seem that the actual freezing and thawing of our material was the main cause of the reduction in the number of positive samples, experienced when culturing from healthy looking fish that had been frozen. Freezing of fish with a presumed low bacterial load prior to bacteriological examination should clearly be avoided.

Homogenisation of the kidney samples did not increase the sensitivity of culture. All 8 fish without internal signs of BKD and 5 of the 32 fish with internal BKD-like lesions also proved negative after homogenisation. Lack of increased sensitivity following homogenising may have been due to an inhibitory effect of tissue toxins in the homogenates, as our procedure did not include the recommended step of washing away any tissue toxins present (Evelyn et al. 1981). The bacterial load in the positive samples was probably too high for any tissue toxins to exert a measureable nega- 
tive effect on sensitivity (all positive samples showed growth of more than 100 R.s. colonies). Homogenisation of kidney samples before inoculation, performed as in the present study, was of no advantage.

Acknowledgements. The authors greatly appreciate the excellent technical work done by Elin Runningen and Elly Soltvedt. This work was supported by a grant from the Norwegian Fishery Research Council.

\section{LITERATURE CITED}

Austin, B., Austin, D. A. (1987), Renibacterium salmoninarum In: Laird, L. H. (ed.) Bacterial fish pathogens. Ellis Horwood Ltd, Chichester, p. 70-81

Austin, B., Embley, T. M., Goodfellow, M. (1983). Selective isolation of Renibacterium salmoninarum. FEMS Microbiol. Lett. 17: 111-114

Austin, B., Rayment, J. N. (1985). Epizootiology of Renibacterium salmoninarum, the causal agent of bacterial kidney disease in salmonid fish. J. Fish Dis. 8: 505-509

Bandín, I., Barja, J. L., Ellis, A. E., Santos, Y., Secombes, S. J (1991). 'In vitro' response of rainbow trout macrophages to Renibacterium salmoninarum. In: Fifth international conference 'Diseases of fish and shellfish'. Budapest, Hungary, August 25-29. Book of abstracts. Fish Culture Research Institute, Szarvas, p. 14

Banner, C. R., Long, J. J., Fryer, J. L., Rohovec, J. S.(1986). Occurrence of salmonid fish infected with Renibacterium salmoninarum in the Pacific Ocean. J. Fish Dis. 9: 273-275

Benediktsdóttir, E., Helgason, S., Gudmundsdóttir, S. (1991) Incubation time for the cultivation of Renibacterium salmoninarum from Atlantic salmon, Salmo salar L., brood fish. J. Fish Dis. 14: 97-102

Bruno, D. W. (1986). Histopathology of bacterial kidney dis ease in laboratory infected rainbow trout, Salmo gairdneri. Richardson, and Atlanctic salmon, SaImo salar, with reference to naturally infecled fish. J. Fish Dis. 9: 523-537

Cipriano, C., Starliper, C. E., Schachte, J. H. (1985) . Comparative sensitivities of diagnostic procedures used to detect bacterial kidney disease in salmonid fishes. J. Wildl. Dis. $2.144-148$

Cottral, G. E. (1978). Preservation and inactivation of microorganisms. In: Cottral, G. E. (ed.) Manual of standardized methods for veterinary microbiology. Cornell University Press, Ithaca, p. 95

Evelyn, T P. T (1977). An improved growth medium for the kidney disease and some notes on using the medium. Bull off. Int. Epiz. 87: 511-513

Evelyn, T. P. T., Bell, G. R., Prosperi-Porta, L., Ketcheson, J. E. (1989). A simple technique for accelerating the growth of the kidney disease bacterium Renibacterium salmoninarum on a commonly used culture medium (KDM2). Dis aquat. Org. $7 \cdot 231-234$

Evelyn, T P. T., Ketcheson, J. E., Prosperi-Porta L. (1981). The clinical significance of immunofluorescence-based diagnoses of the bacterial kidney disease carrier Fish Pathol 15: $239-300$

Evelyn, T P. T., Prosperi-Porta, L., Ketcheson, J. E. (1990). Two new techniques for oblaining consistant results when

Responsible Subject Editor: T Evelyn, Nanaimo, B.C., Canada growing Renibacterium salmoninarum on KDM2 culture medium. Dis. aquat. Org. 9: 209-212

Goodfellow, M., Embley, T M., Austin, B. (1985). Numerical taxonomy and emended description of Renibacterium salmoninarum. J. gen. Microbiol. 131. 2739-2752

Gudmundsdóttir, S., Benediktsdóttir, E., Helgason, S. (1990). Comparison of an enzyme-linked immunosorbent assay and cultivation on a selective mdium for the detection of Renibacterium salmoninarum in Atlantic salmon brood fish. In: Bacterial diseases of fish, Institute of Aquaculture, University of Stirling, Scotland, June 26-29. Conference Handbook. University of Stirling, Stirling, p. 47

Gudmundsdóttir, S., Helgason, S., Benediktsdóttir, E. (1991) Comparison of the effectiveness of three different growth media for primary isolation of Renibacterium salmoninarum from Atlantic salmon, Salmo salar L., brood fish. J Fish Dis. 14: 89-96

Håstein, T., Dale, O. B. (1987). Registrations of bacterial kidney disease in Norway 1980-87. In: European Ass. Fish Pathologists Third Int. Conf., Bergen, Norway. August 31 - September 3. Poster-Abstracts. Bergen, p. 8

Martin, S. W., Meek, A. H., Willeberg, P. (1988) Measurement of disease frequency and production. In: Martin, S. W. (ed.) Veterinary epidemiology, principles and methods. Iowa State University Press, Ames, p. 74

Paclibare, J. O., Evelyn, T. P. T., Albright, L. J. (1988). A. comparative evaluation of various methods for detecting the kidney disease bacterium (Renibacterium salmoninarum) in salmonids. In: International Fish Health Conference, Vancouver, B.C., Canada, July 19-21, Conference Handbook. Fish Health Section, American Fisheries Society, Vancouver, p. 178

Pascho, R. J., Elliott, D. G., Mallett, R. W., Mulcahy, D. (1987) Comparison of five techniques for the detection of Renibacterium salmoninarum in adult coho salmon. Trans Am. Fish. Soc. 116: 882-890

Sakai, M., Koyama, G., Atsuta, S., Kobayashi, M. (1987) Detection of Renibacterium salmoninarum by a modified peroxidase antiperoxydase (PAP) procedure. Fish Pathol. 22(1): $1-5$

Sanders, J. E., Fryer, J. L. (1980). Renibacterium salmoninarum gen. nov., sp. nov., the causative agent of bacterial kidney disease in salmonid fishes. Int. J. syst. Bacteriol. 30 $496-502$

Sandven, P., Solberg, O., Ødegaard, K., Myhre, G. (1982). Improved medium for the transportation of gonococcal specimens. Acta pathol. microbiol. scand. (Sect. B) 90 : $73-77$

Shortt, T. A., Olivier, G., Elner, J. K. (1988). Comparison of the fluorescent antıbody (FA) and culture techniques for detecting bacterial kidney disease (BKD) in Atlantic salmon (Salmo salar). In: International Fish Health Conference, Vancouver, B.C., Canada, July 19-21, Conference Handbook. Fish Health Section, American Fisheries Society, Vancouver, p. 85

Wiens, G. D., Kaattari, L. (1989). Monoclonal antibody analysis of common surface protein(s) of Renibacterium salmoninarum. Fish Pathol. 24: 1-7

Young, C. L., Chapman, G. B. (1978). Ultrastructural aspects of the causative agent and renal histopathology of bacterial kidney disease in brook trout (Salvelinus fontalis). J. Fish Res. Bd Can. 35: 1234-1248

Manuscript first received: April 16, 1991

Revised version accepted: August 21, 1992 